\title{
Cross-generational syntactic variation in Mundaka Basque: the influence of the language of instruction
}

\author{
Ager Gondra \\ SUNY-Purchase
}

\begin{abstract}
This article examines syntactic variation in relative clause $(R C)$ constructions in Mundaka Basque among two groups of Mundaka Basque speakers. The language of instruction the Mundaka Basque speakers had in school draws the line that separates the two populations: the first group (Mundaka Basque I) had Spanish as the language of instruction and no Basque as a subject, while the second one (Mundaka Basque II) had Standard Basque as the language of instruction and Spanish as a subject. The results of an experiment involving a cloze test show that differences in production between these populations depends on the grammaticality of RCs with an indirect object or adjunct gap and a subject or direct object RC head: for Mundaka Basque I relativization under this configuration is grammatical, while for Mundaka Basque II, it is not. This variation is due to simplification of relativization accessibility in Mundaka Basque II caused by Standard Basque.
\end{abstract}

Keywords: Sociolinguistics, relative clause, syntactic variation, cloze test, educational system, simplification.

\section{Introduction*}

Sociolinguists and other scholars of Basque (Bonaparte 1863, Michelena 1954, 1977, Tovar 1959, Irizar 1992, Trask 1997, Zuazo 1997, 1998a,b, 2010, Amorrortu 2000, Olano 2000, Zubiri 2000, Haddican 2005) have long identified regional variation in Basque, but little work has been carried out to identify how varieties of this language are changing over time, particularly under the influence of contact with Standard Basque. This article examines syntactic change in relative clause (RC) constructions within Mundaka Basque and identifies two cross-generational varieties: Mundaka I and Mundaka II (henceforth, MB I and MB II respectively). The difference between these

* I gratefully acknowledge the help I obtained from Elena Benedicto, Elaine Francis and Jon Franco. 
varieties relies on the grammaticality of RCs with an indirect object and adjunct gap and a subject or direct object RC head. In MB I, this configuration is grammatical (1a-b). The head of the RC shows the Case ${ }^{1}$ assigned within the embedded clause: mutileri 'to the boy' in (1a) and mutilekaz 'with the boys' in (1b). Furthermore, the main auxiliary verb shows number agreement with the head: singular in (1a) and plural in (1b).

(1) Mundaka Basque I

a. $\left[\left[e_{\mathrm{i}}\right.\right.$ Sagarra emon dotsaten $]$ mutileri $\left.{ }_{\mathrm{i}}\right]$ jeusi ein da. ø.DAT apple.D.ABS give aux.A3sD3sE1s-c boy.D.DAT fall do aux.A3s 'The boy that I gave the apple to has fallen down'

b. $\left[\left[e_{\mathrm{i}}\right.\right.$ Etorri nintzen $]$ mutilekaz $\left.{ }_{\mathrm{i}}\right]$ etxie erosi dabe. ø.soc come aux.A1s-C boy.D.soc house.D buy aux.A3se3pl 'The boys that I came with has bought the house'

In $\mathrm{MB}$ II, on the other hand, relativization under this configuration is not allowed (2a-b). The head of the RC can neither carry the Case assigned within the embedded clause nor the Case assigned in the main clause.

(2) Mundaka Basque II

a. $\left[\left[e_{\mathrm{i}}\right.\right.$ Sagarra emon dotsaten $] \quad{ }^{*}$ mutileri $_{\mathrm{i}} /{ }^{*}$ mutile $\left._{\mathrm{i}}\right]$ jeusi ø.DAT apple.D.ABs give aux.A3sD3sE1s-C boy.D.DAT/ boy.D.ABs fall ein da. do aux.A3s

'The boy that I gave the apple to has fallen down'

b. $\left[\left[e_{\mathrm{i}}\right.\right.$ Etorri nintzen $]{ }^{*}$ mutilegaz $_{\mathrm{i}} /{ }^{*}$ mutilek $\left._{\mathrm{i}}\right]$ etxie erosi ø.soc come aux.A1s-C boy.D.soc/ boy.D.ERG house.D buy dabe.

aux.A3sE3pl

'The boy that I came with has bought the house'

This article is structured into four sections: Section 2 describes the socio-historical situation of Basque and the educational system in the Basque Autonomous Community. Section 3 runs two experiments in order to identify two Mundaka Basque varieties and their speakers. Section 4 discusses the similarities and differences between MB I and MB II and provides an explanation to the existence of these two varieties. Section 5 concludes the main points established in this article.

\section{Basque and its status}

Basque is a minority language, which is in contact with its neighbors: French in the Northern Basque Country and Spanish in the Southern Basque Country. The situation of Basque is related to the specific context of the Basque language and it is the result of a large number of social, historical and economical factors. This sec-

${ }^{1}$ Erg - Ergative; Abs - Absolutive; Dat - Dative; Ine - Insesive; Soc - Sociative; Ela - Elative; Bef Benefactive. 
tion provides a brief description of the socio-cultural situation of Basque during the Spanish dictatorship together with the present day democracy in Spain and the present educational system in the Basque Autonomous Community.

\subsection{The socio-political situation of Basque}

According to Zalbide and Cenoz (2009) Basque and Spanish have been in contact in the Basque Autonomous Community (henceforth BAC) for centuries, during which Basque suffered from diglossia. The most critical stage for the Basque language came during Franco's dictatorship (1939-1975), in which it was prohibited to use the Basque language; therefore it was also excluded from the public domain, including education. For all these reasons, the largest part of the population in BAC shifted from being mainly Basque dominant bilinguals to Spanish dominant bilinguals or even just Spanish monolinguals.

At the end of the dictatorship, the Spanish Constitution (1978) declared Spanish the nationwide official language and guaranteed the rights of Spanish speakers to use their language but also raised the possibility of recognizing other languages as coofficial in their own territories. Finally, after important political changes and strong social movements to support Basque, The Basque Autonomous Community Statute of Autonomy (1979) states that Basque has, like Spanish, the status of an official language in the Basque Autonomous Community. Thus, Basque citizens have the right to know and use both languages in this territory.

\subsection{The educational system}

In 1982, a bilingual educational system was created, which is currently the main domain of social functioning for the Basquization and bilingualization of the inhabitants throughout the BAC (Azurmendi et al. 2006, 2008, Cenoz et al. 2006, Etxebarria et al. 2008, EUSTAT 2004, Gardner 2000, Gardner et al. 2005, Grin et al. 1999, Luque 2004, Martínez de Luna et al. 2000). Regarding the language instruction, there are three models of education in the Basque Autonomous Community, traditionally referred to as models $\mathrm{A}, \mathrm{B}$ and $\mathrm{D}$ in ascending order of exposure to Basque (Zalbide and Cenoz 2009). It is important to highlight that the variety of Basque used in education is none of the main five dialects (Biscayan, Gipuzkoan, Upper Navarrese, Navarrese-Lapurdian and Zuberoan; cf. Zuazo 1998a), but a variety called Batua, which is considered nowadays Standard Basque. This standard version of Basque was created in the 1970s by the Euskaltzaindia (Academy of the Basque Language), mainly based on the central Basque dialect, that is, Gipuzkoan, and on the written tradition (Zuazo 2010).

Model A

Spanish is the language of instruction in this model and Standard Basque is taught as a second language for three to five hours a week. Sierra (2009) explains that even though according to the legal framework students are expected to be competent 
in both official languages by the end of compulsory education, the results indicate that the proficiency in Basque achieved by students is far from native-like.

Model B

Both Standard Basque and Spanish are used as languages of instruction for approximately $50 \%$ of school time, although there is considerable variation from school to school.

\section{Model D}

Standard Basque is the language of instruction in this model and Spanish is taught as a subject for four to five hours a week. This can be regarded as both total immersion programs for native Spanish speaking students as well as first language maintenance programs for native Basque speakers (Zalbide and $\mathrm{Cenoz}$ 2009). In addition, Azurmendi, Larranaga and Apalategi (2008) claim that this Basque immersion model is the one that really guarantees basquization and bilingualization.

\section{Syntactic variations within Mundaka Basque}

This section identifies two varieties among Mundaka Basque speakers. In addition, by doing so it recognizes the speakers of these varieties. In order to achieve these goals, two experiments involving a cloze test (Hadley and Naaykens 1997) were conducted.

First, this section introduces the participants of both experiments. Second, it describes the procedure for both cloze tests. Third and last, it presents the material and the results of each test.

\subsection{Participants}

Thirty-two participants were recruited in Mundaka. The participants had to answer an oral questionnaire before the experiments began. All of them were self-reported both euskadun zaharrak of Mundaka Basque (native speakers of Mundaka Basque) as well as native speakers of Spanish, and to have lived their whole life in Mundaka. Nevertheless, the language of instruction the participants had in school draws the line that separates the two populations. Since the participants of group A (8 male / 8 female) went to school before the bilingual system was created, they had Spanish as the language of instruction and no Standard Basque as a subject. Hence, the only Basque input group A had was Mundaka Basque and this input was all from non-instructional environments. Group B (8 male / 8 female), on the other hand, went to school after the bilingual system was created. Additionally, since they were in Model D, they had Standard Basque as the language of instruction and Spanish as a subject for four to five hours a week. Thus, group B had non-instructional input of Mundaka Basque and instructional input of Standard Basque. 


\subsection{Procedure for experiments I-II}

A cloze test was used in both experiments (Hadley and Naaykens 1997). Participants saw a sentence with a blank in it and a picture. This picture created the context that helped the participants to fill the blank. The blank was always the position in which the head of the relative construction was going to be. See Figure 1 for an example. The English gloss and translation were added into this Figure to help the reader understand the example:

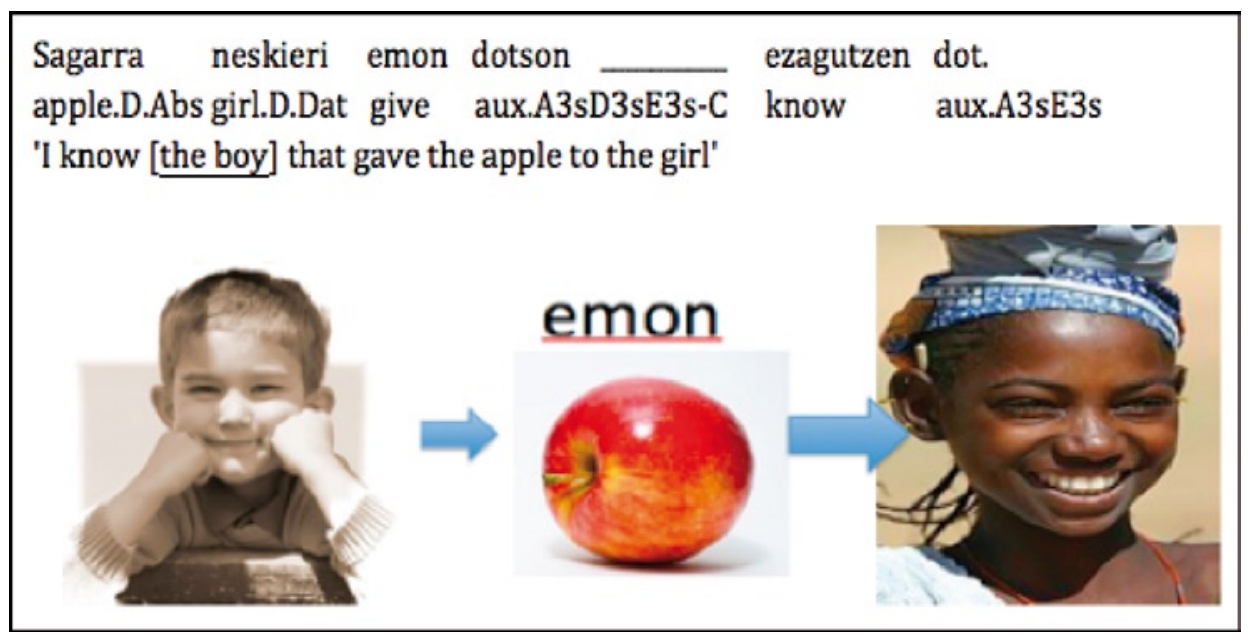

Figure $1^{2}$

Cloze test

The 32 participants (16 from group A and 16 from group B) were asked in Mundaka Basque to try to fill the blank using the picture as a guide. There is no time constraint: participants can choose when to move on to the next sentence. Both sessions are audio recorded and the data is transcribed and coded in The Language Archive (henceforth ELAN). ELAN is a software tool for the creation of complex annotations on video and audio resources. Three tiers are created in ELAN: in the first one the output is transcribed in Basque, in the second one the output is translated into English, and in the third one the output is coded. Then the transcribed and coded data are aggregated in interlinearized text format and exported to a spreadsheet. Finally, all data are subjected to statistical tests applying an analysis of variance (ANOVA).

\footnotetext{
2 Pictures courtesy of Wikipedia.

http://en.wikipedia.org/wiki/File:Felicidade_A_very_happy_boy_2.jpg

http://en.wikipedia.org/wiki/File:Red_Apple.jpg

http://en.wikipedia.org/wiki/File:Young_Peul_girl_in_Mali.jpg
} 


\subsection{Experiment I: type of gap: ergative and absolutive Case}

\subsubsection{Sentence materials}

In the first elicitation task two types of gaps were tested: ergative and absolutive Case gaps. Three types of RC head function: (i) subject or direct object with the opposite structural Case ${ }^{3}$ (ergative or absolutive Case), (ii) indirect object and (iii) adjunct (sociative, elative or benefactive). Example sentences for each possible combination are given in (3a-f):

a. $e_{i} \quad$ Sagarra erosi dauen __ ezagutzen dot. ø.ERG apple.D.ABs buy aux.A3se3s-C know aux.A3se1s 'I know [the boy] that bought the apple's

b. $e_{i} \quad$ Sagarra erosi dauen __ etortzeko esan dotsat. ø.ABS apple.D.ABs buy aux.A3sE3s-C to come say aux.A3sD3sE1s 'I told [the child] that bought the apple to come'

c. $e_{i} \quad$ Sagarra erosi dauen __etri nai. ø.ABS apple.D.ABs buy aux.A3se3s-C come aux.A1s. 'I came [with the boy] that bought the apple'

d. Mutilek $e_{i}$ erosi dauen_apurtu doste_ hagine. boy.D.ERG $\emptyset . A B S$ buy aux.A3SE3s-C break auX.A3SD3SE1s tooth.D.ABS 'I broke my tooth [with the apple] that the boy bought' (Lit: '[The apple] that the boy bought broke my tooth')

e. Mutilek $e_{i}$ erosi dauen azala kendu dotsat. boy.D.ERG Ø.ABs buy aux.A3sE3s-C skin.D.ABs peel aux.A3SD3sE1s 'I skinned [the apple] that the boy bought' (Lit: 'I take out the skin [to the apple] that the boy bought')

f. Mutilek $e_{i}$ erosi dauen_ein dot pastela. boy.D.ERG ø.ABS buy aux.A3sE3s-C make aux.A3sE1s cake.D.ABS 'I made the cake [with the apple] that the boy bought'

Thus, the design crossed the following factors: type of gap (ergative or absolutive Case), and function of the RC head (subject/direct object with the opposite structural Case, indirect object and adjunct). This resulted in gap type $\times \mathrm{RC}$ head function $=2 \times 3=6$ items per set. Each set repeats 4 times: $6 \times 4=24$ items. As controls, 24 simple sentences with one random blank (e.g. subject, direct object, or the auxiliary verb) in each of them were included, yielding a total of 48 stimuli. These stimuli were randomized and counterbalanced. After explaining to the participants the instructions, they proceeded to the practice phase, in which each participant completed four sentences. Right after, they started with the stimuli to be analyzed.

3 The head of the RC is in absolutive Case position when the gap is in ergative Case position, and vice versa.

4 The material in square brackets corresponds to the intended filler of the gap in each sentence item. 


\subsubsection{Results}

Figure 2 and Figure 3 graph the proportion of target sentences produced by group A and group B respectively.

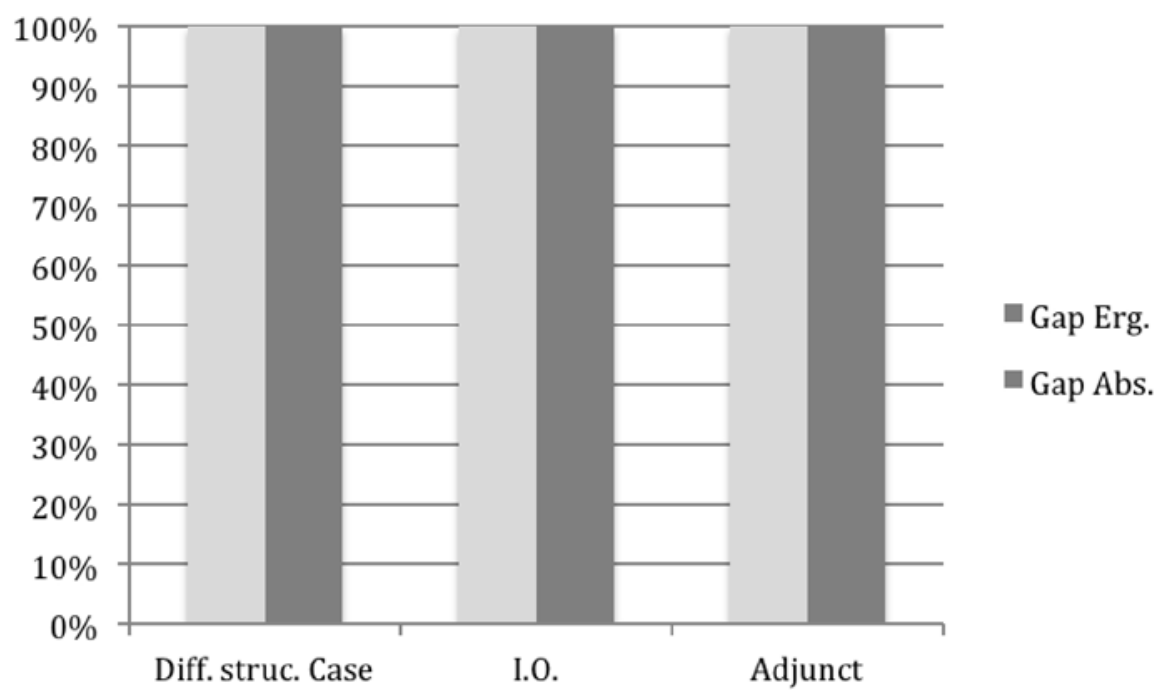

Figure 2

Percentage of target responses produced by group A

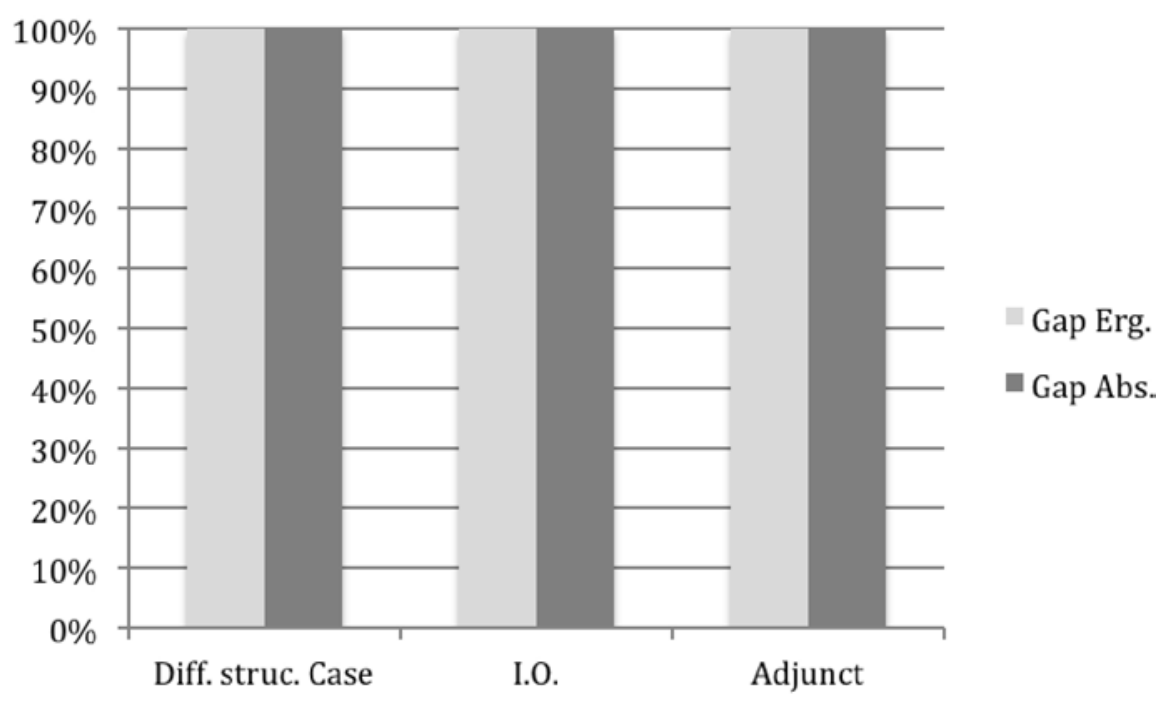

Figure 3

Percentage of target responses produced by group B 
A two-way ANOVA was run to test the effects of gap type and RC head function in both groups. The ANOVA did not yield significant main effects $(<0.05)^{5}$ of gap type, that being ergative or absolutive Case, $\mathrm{RC}$ head function, and interaction of these two in any of the two groups. In other words, both groups showed no restriction constructing RC with any external DP (subject/direct object, indirect object or adjunct) and with any type of gap (ergative or absolutive Case).

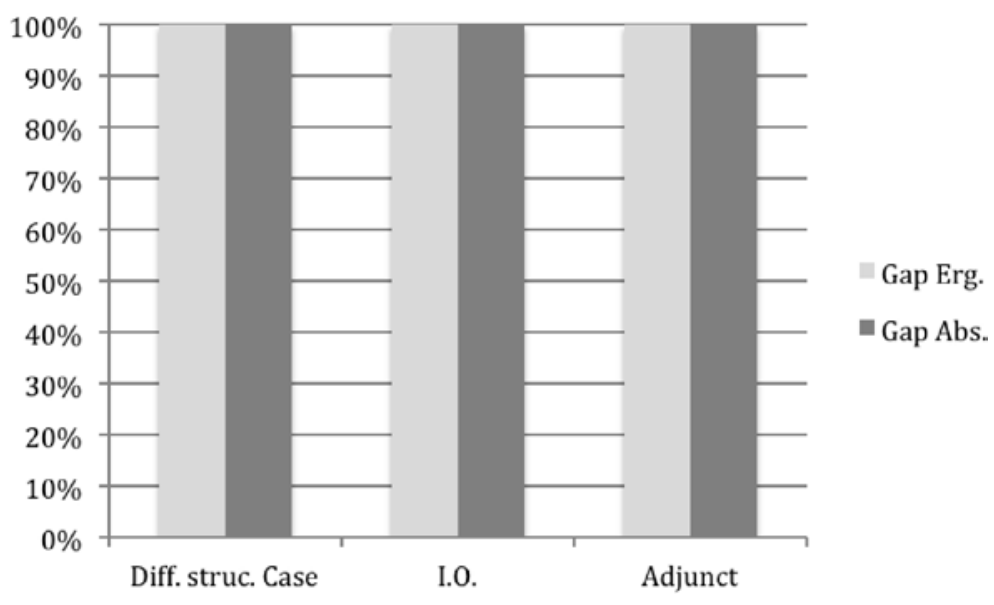

Figure 4

Percentage of target responses with external Case by group A

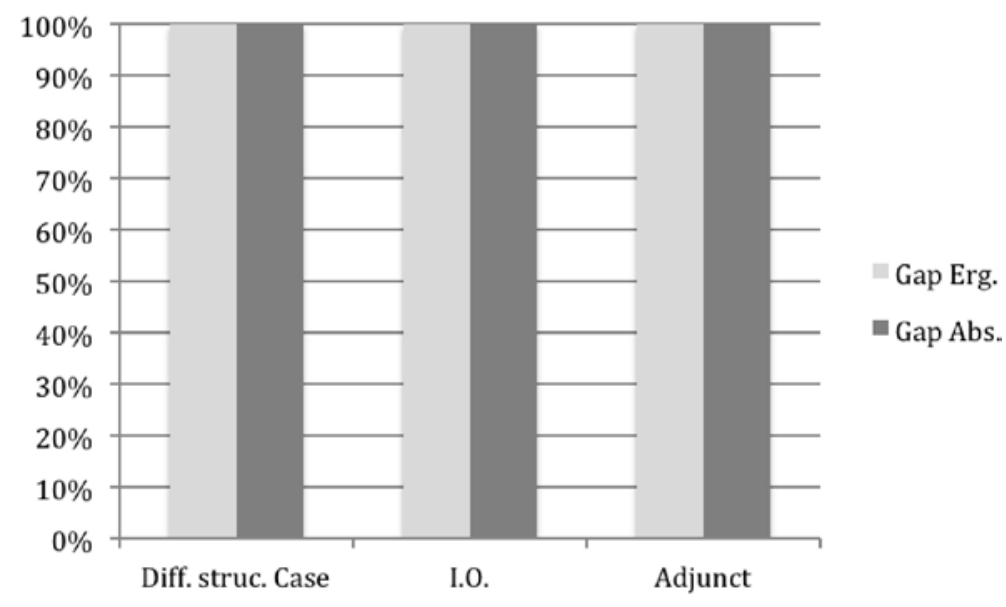

Figure 5

Percentage of target responses with external Case by group B

5 ANOVA stopped because of infinite likelihood. 
Figure 4 and Figure 5 show the proportion of target responses with the external Case of group A and B respectively. For the sake of simplification, I call internal Case to the Case assigned within the RC, while external Case to the Case assigned outside the RC.

Given the type of RC head function for the external Case dependent variable, there is no significant difference between groups $(F(1,183)=0.06 ; p=0.81)$, gap type $(\mathrm{F}(1,183)=0.28 ; \mathrm{p}=0.59)$, $\mathrm{RC}$ head function $(\mathrm{F}(1,183)=0 ; \mathrm{p}=1)$, interaction of group and $\mathrm{RC}$ head function $(\mathrm{F}(1,183)=0 ; \mathrm{p}=1)$, gap type and $\mathrm{RC}$ head function $(F(1,183)=0 ; p=1)$, group and gap type $(F(1,183)=0.14 ; p=0.70)$ and group, gap type and $\mathrm{RC}$ head function $(\mathrm{F}(1,183)=0 ; \mathrm{p}=1)$. Hence, the head of the RCs with an ergative or absolutive Case gap always showed the external Case no matter its function.

\subsection{Experiment II: type of gap: adjunct and indirect object}

\subsubsection{Sentence materials}

In the second elicitation task four types of gaps were tested: indirect object, sociative, elative and benefactive Case. Three types of RC head functions: subject/direct object, I.O. or adjunct with a different Case from that of the gap, and I.O. or adjunct with a Case matching the one of the gap. Example sentences for each possible combination are given in (4a-l):

(4) a. Farmazeutikiek $e_{i}$ aspirinie emon dotson pharmacist.D.ERG ø.DAT aspirin.D.ABS give aux.A3sD3sE3s-C my aitsitse da. grandfather be.3s

'[The man] that the pharmacist gave the aspirin to is my grandfather'

b. Sagarra $e_{i} \quad$ emon dotsaten etorri nai. apple.D.ABs ø.DAT give aux.A3sE1s-C come aux.A3s 'I came [with the kid] that I gave the apple to'

c. Farmazeutikiek $e_{i}$ aspirinie saldu dotson emon pharmacist.D.ERG ø.DAT aspirin.D.ABS sell auX.A3SE3s-C give dotsat dirue. aux.A3sD3se3s money.D

'I gave money [to the man] that the pharmacist sold the aspirin to'

d. $e_{i} \quad$ Etorri nintzen etxie erosi deu. ø.SOC come aux.A1s-C house.D.ABs buy aux.A3sE3s '[The girl] that I came with bought the house'

e. Mutile $e_{i}$ korrikan dabilen boy.D.ABs $ø . s 0 c$ run be.A3s-C jatekoa emon dotsat. aux.A3sD3se3s

'I gave the food [to the dog] that the boy is running with' 
f. Mutile $e_{i} \quad$ korrikan dabilen ___ joaten nai hondartzara. boy.D.ABS ø.soc run be.A3s-C go aux.A1s beach.D.ALL

'I go to the beach [with the dog] that the boy runs with'

g. $e_{i} \quad$ Urten naien pizza onak eitzen deuz. ø.INE leave be.A3s-C pizza good.D.pl do aux.A3ple3ps 'The pizzeria] I left makes good pizzas'

h. Andrak $e_{i}$ pase diren galdetu deu Mariak. woman.D.pl.ERG ø.ELA pass aux.A3pl-c ask aux.A3s3s Maria.ERG 'Maria asked [about the plaza] that the women passed by'

i. $e_{i} \quad$ Urten naien __ dator Antxon. ø.ELA leave beA.3s-C come.A3s Antxon.ABs 'Antxon is coming [from the bar] that I left'

j. Baloie $e_{i}$ erosi doten __ eitzen deuz urtiek ball.D.ABS $\varnothing$. BEN buy aux.A3sE1s-C do aux.A3ple3s year.D.pl.A 'It is the birthday of [the boy] I bought the ball for' (Lit: 'The boy that I bought the ball for makes years')

k. Aitorrek dirue $e_{i}$ eskatu dauen ___ berba eitzen Aitor.ERG money.D.ABS ø.BEN ask aux.A3sE3s-C talk.ABs do dot. aux.3s1s 'I am speaking [with the man] that Aitor requested money for'

1. Baloie $e_{i}$ erosi doten__ dire futboleko zapatak. ball.D.ABs ø.BEN buy aux.A3sE1s-C be.A3pl football.GEN shoe.D.pl.ABS 'The cleats are [for the girl] that I bought the ball for'

The factors of the design are the following: type of gap (indirect object, sociative, elative or benefactive Case), and function of the RC head (subject/object, I.O. or different Case adjunct and matching Case I.O. or adjunct). This resulted in gap type $\times \mathrm{RC}$ head function $=4 \times 3=12$ items per set. Each set repeats 4 times: $12 \times 4=48$ items. As controls, I included 42 simple sentences with a random blank in each, yielding 90 stimuli in total. These stimuli were randomized and counterbalanced. After explaining to the participants the instructions in Mundaka Basque, each participant completed four sentences as practice. The data to be analyzed started from the fifth sentence.

\subsubsection{Results}

Figure 6 graphs the percentage of target sentence production of both groups with the head of the RC in subject or direct object position. 


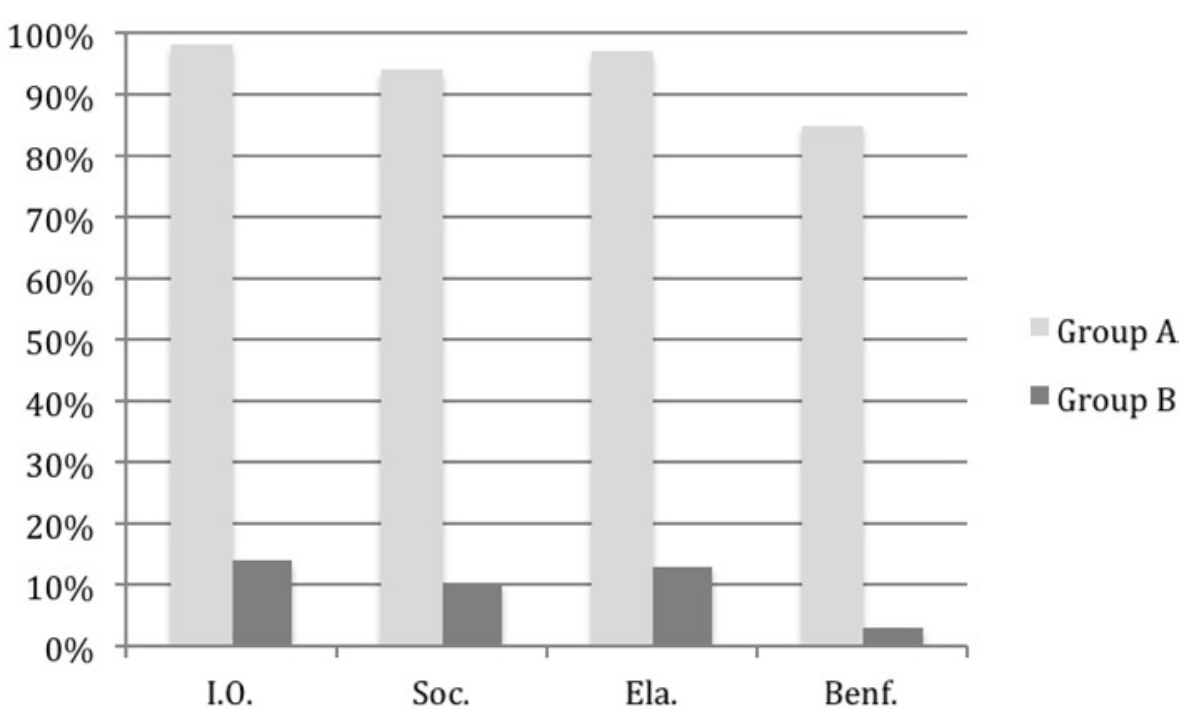

Figure 6

Percentage of target sentences produced

First, measuring target sentences produced (Figure 6), a one-way ANOVA was run to test the effects of gap type and group for all cases in which the RC Head functions as a subject or object. There was a significant difference in group $(\mathrm{F}(1,120)=157.97 ; \mathrm{p}<.0001)$ type of gap $(\mathrm{F}(4,120)=12.98 ; \mathrm{p}<.0001)$, and interaction between group and gap $(\mathrm{F}(4,120)=6.28 ; \mathrm{p}<.0001)$. Hence, group $\mathrm{A}$ completed sentences such (5a-d) while group B did not.

(5) a. Farmazeutikiek $e_{i}$ aspirinie emon dotson ___ nire pharmacist.D.ERG ø.DAT aspirin.D.ABS give aux.A3sD3sE3s-C my aitsitse da. grandfather be. $3 \mathrm{~s}$

'[The man] that the pharmacist gave the aspirin to is my grandfather'

b. $e_{i} \quad$ Etorri nintzen etxie erosi deu.

ø.soc come aux.A1s-C house.D.ABs buy aux.A3sE3s

'[The girl] that I came with bought the house'

c. $e_{i} \quad$ Urten naien pizza onak eitzen deuz. ø.INE leave be.A3s-c pizza good.D.pl do aux.A3ple3ps '[The pizzeria] I left makes good pizzas'

d. Baloie $e_{i}$ erosi doten __ eitzen deuz urtiek ball.D.ABS $\emptyset . B E N$ buy aux.A3sE1s-C do aux.A3ple3s year.D.pl.A 'It is the birthday of [the boy] I bought the ball for' (Lit: 'The boy that I bought the ball for makes years') 
Figure 7 graphs the target responses with internal Case of both groups with the head of the RC in subject or direct object position.

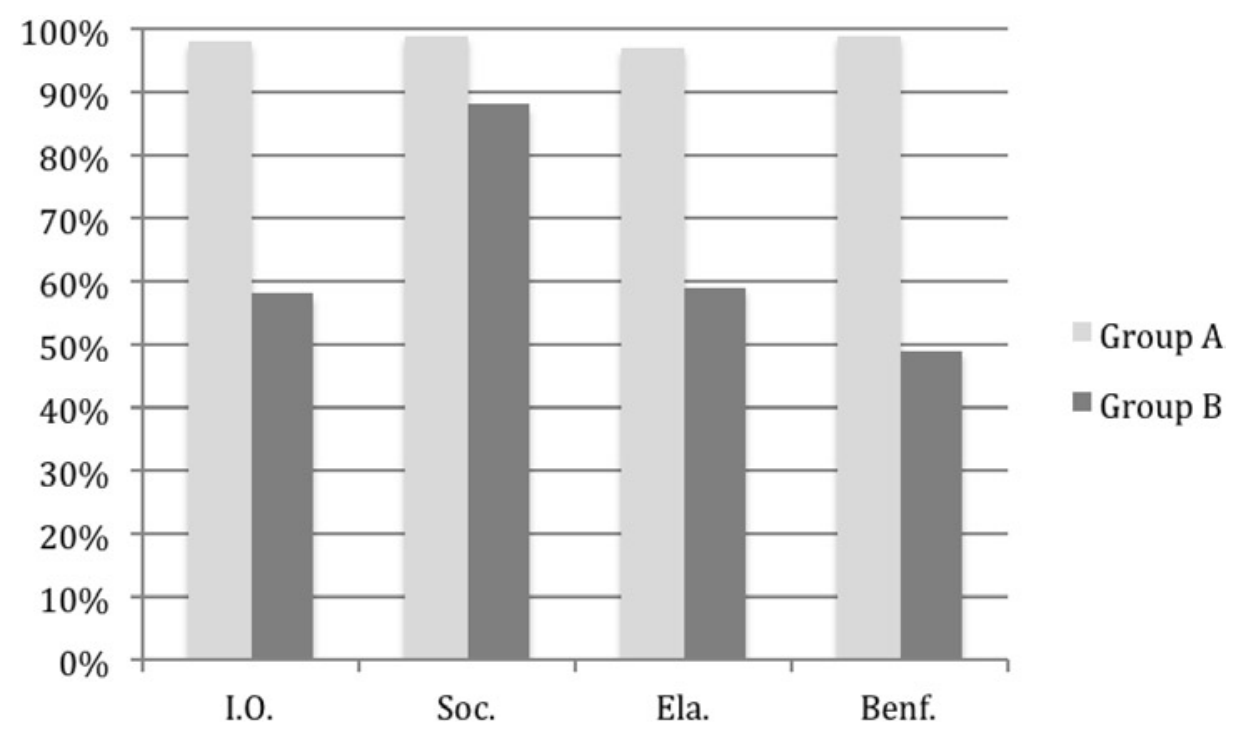

Figure 7

Percentage of target responses with internal Case

Measuring participants' choice of Case marking (Figure 7), a one-way ANOVA was run to test the effects of gap type and group for all cases in which the RC head functions as an subject or object. There was a significant main effect of group $(\mathrm{F}(1,120)=157.97 ; \mathrm{p}<.0001)$, a significant main effect of gap $(\mathrm{F}(4,120)=12.98$; $\mathrm{p}=.0001)$ and a significant interaction of group and gap $(\mathrm{F}(4,120)=6.28$; $\mathrm{p}<.0001)$. Thus, the participants of group B did not show a clear preference for either internal or external Case while building the sentences. On the contrary, participants of group A showed a clear preference for internal Case.

Figure 8 graphs the proportion of target responses produced with RC of I.O. or different adjunct type by group $A$ and group $B$. 


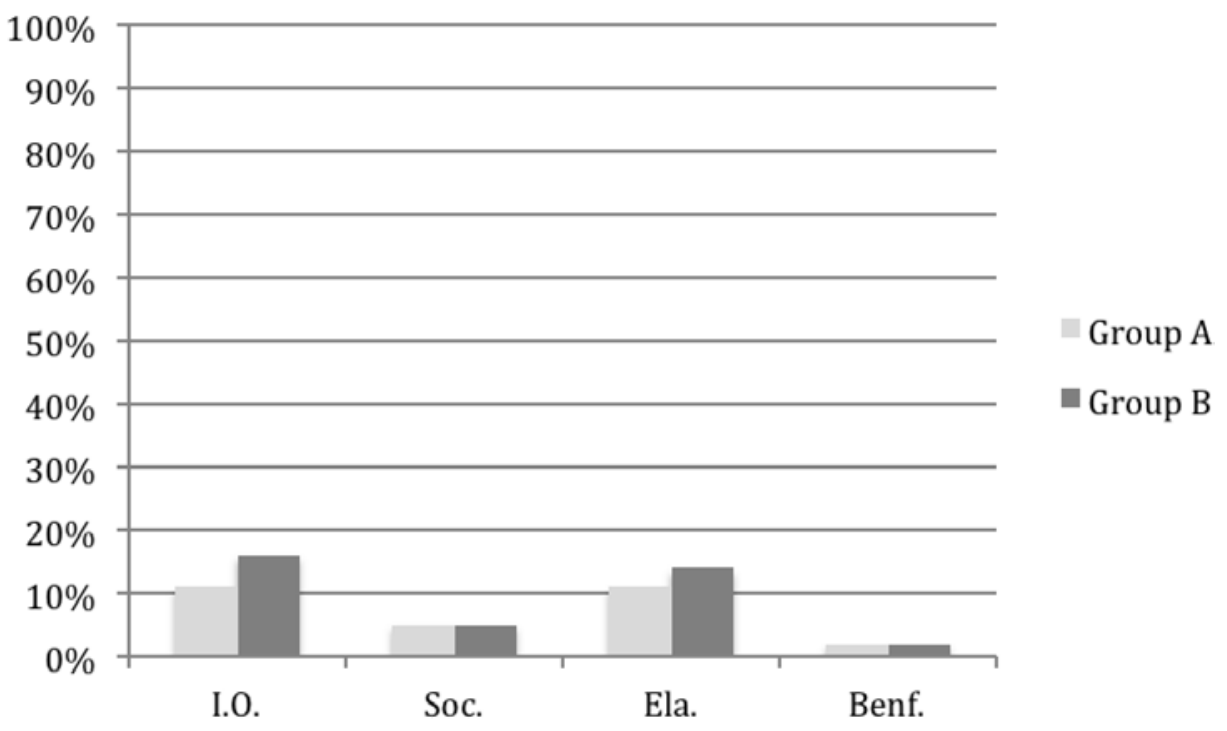

Figure 8

Percentage of target responses produced with RCs of non- matching I.O. and adjunct type

Measuring target sentences produced, a one-way ANOVA was run to test the effects of gap type and group for all cases in which the RC head functions as an I.O. or adjunct with a different case requirement than the gap (non-matching I.O. or adjunct). As shown in Figure 8, given different adjunct RC head for produced sentence, there is significant difference among gaps $(F(4,120)=120.63$; $\mathrm{p}<.0001)$, yet not among groups $(\mathrm{F}(1,120)=0.52 ; \mathrm{p}=0.47)$, and interaction of group and gap $(\mathrm{F}(4,120)=1.42 ; \mathrm{p}=0.23)$. Therefore, neither the participants of group A nor the participants of group B completed sentences such as (6a-d):

(6) a. Sagarra emon dotsaten etorri nai. apple.D.ABs ø.DAT give aux.A3sE1s-C come aux.A3s 'I came [with the kid] that I gave the apple to'

b. Mutile $e_{i} \quad$ korrikan dabilen boy.D.ABs ø.soc run be.A3s-C jatekoa emon dotsat. food.D.ABs give aux.A3sD3sE3s 'I gave the food [to the dog] that the boy is running with'

c. Andrak $e_{i}$ pase diren galdetu deu Mariak. woman.D.pl.ERG ø.ELA pass aux.A3pl-c ask aux.A3s3s Maria.ERG 'Maria asked [about the plaza] that the women passed by' 

d. Aitorrek dirue
$e_{i} \quad$ eskatu dauen berba eitzen Aitor.ERG money.D.ABs ø.BEN ask aux.A3sE3s-C talk.ABs do dot. aux.3s $1 \mathrm{~s}$
'I am speaking [with the man] that Aitor requested money for'

Figure 9, on the contrary, projects the proportion of target responses produced with RC of matching I.O. or adjunct type produced by both groups.

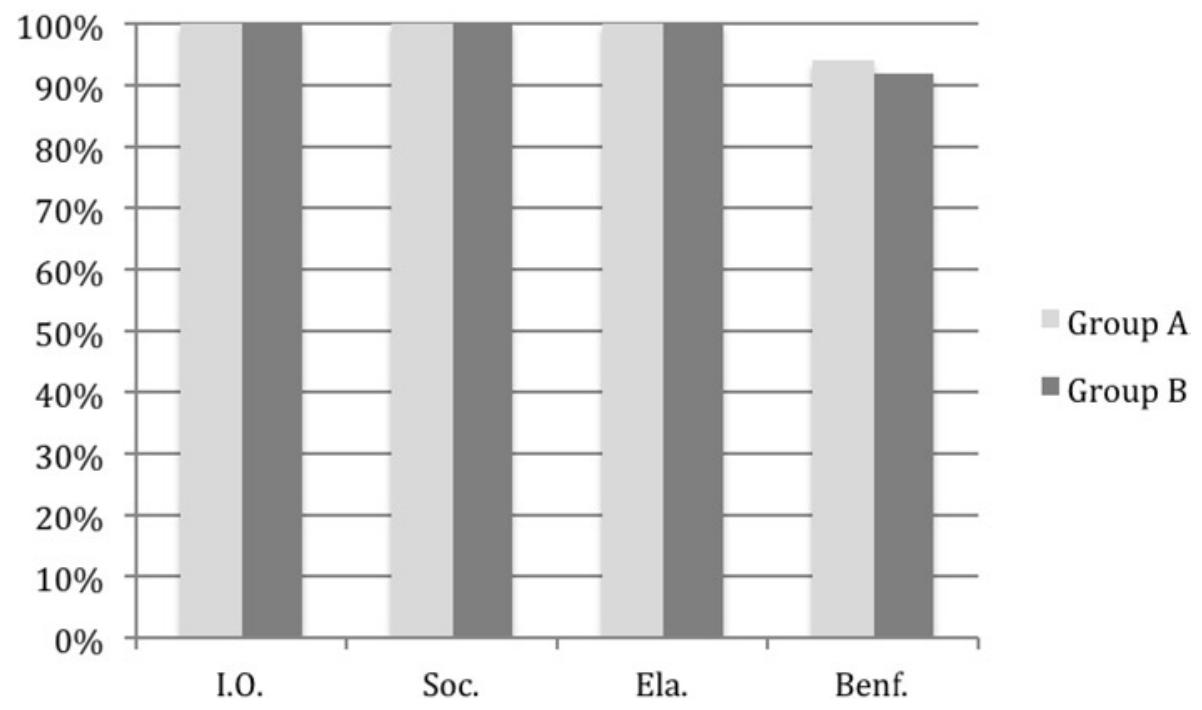

Figure 9

Percentage of target responses produced with RCs of matching I.O. and adjunct type

A one-way ANOVA was run to test the effects of gap type and group for the cases in which the I.O. or adjunct type in the relative clause matched that of the main clause (matching adjunct). As shown in Figure 9, there is no significant difference between groups $(\mathrm{F}(1,120)=0.48 ; \mathrm{p}=0.49)$, no significant effect of gap type $(\mathrm{F}(4,120)=0.62 ; \mathrm{p}=0.93)$, and no significant interaction of group and gap $(F(4,120)=0.48 ; p=0.75)$. Hence, the participants of both groups built sentences such as $(7 \mathrm{a}-\mathrm{d})$

(7) a. Farmazeutikiek $e_{i}$ aspirinie saldu dotson emon pharmacist.D.ERG ø.DAT aspirin.D.ABS sell auX.A3sE3s-C give dotsat dirue.

aux. A3sD3se3s money.D

'I gave money [to the man] that the pharmacist sold the aspirin to'

b. Mutile $e_{i}$ korrikan dabilen joaten nai hondartzara. boy.D.ABs ø.soc run be.A3s-c go aux.A1s beach.D.ALL 'I go to the beach [with the dog] that the boy runs with' 
c. $e_{i} \quad$ Urten naien dator Antxon. ø.ELA leave bea.3s-c come.A3s Antxon.ABs 'Antxon is coming [from the bar] that I left'

d. Baloie $e_{i}$ erosi doten ___ dire futboleko zapatak. ball.D.ABS $\varnothing . B E N$ buy aux.A3se1s-C be.A3pl football.GEN shoe.D.pl.ABS 'The cleats are [for the girl] that I bought the ball for'

\section{Discussion and analysis}

The results obtained from the first cloze test show that both Mundaka Basque varieties can always construct $\mathrm{RCs}$ with the gap in ergative $(8 \mathrm{a}-\mathrm{c})$ or absolutive Case (8d-f). These examples show that the head of the $\mathrm{RC}$ carries the Case required by the main verb.

(8) a. $\left[\left[e_{\mathrm{i}}\right.\right.$ Sagarra erosi dauen $]$ mutile $\left.e_{\mathrm{i}}\right]$ ezetzen dot. ø.ERG apple.D.ABs buy aux.A3sE3s-C boy.D.ABS know aux.A3sE1s 'I know the boy that bought the apple'

b. $\left[\left[e_{\mathrm{i}}\right.\right.$ Sagarra erosi dauen $]$ mutileri $\left.{ }_{\mathrm{i}}\right]$ emon dotsat ø.ERG apple.D.ABs buy aux.A3sE3s-C boy.D.DAT give aux.A3sD3sE3s etxie.

house.D.ABS

'I gave the house to the boy that bought the apple.

c. $\left[\left[e_{\mathrm{i}}\right.\right.$ Sagarra erosi dauen $]$ mutilegaz $]$ etorri nai. ø.ERG apple.D.ABs buy aux.A3sE3s-C boy.D.SOC come aux.ABs1s. 'I came with the boy that bought the apple'

d. [[Mutilek $e_{\mathrm{i}}$ erosi dauen] sagarra $\mathrm{i}_{\mathrm{i}}$ jan dot boy.ERG ø.ABs buy aux.A3sE3s-C apple.ABS eat aux.A3sE1s 'I ate the apple that the boy bought'

e. [[Mutilek $e_{\mathrm{i}}$ erosi dauen] sagarrari $\left.\mathrm{i}_{\mathrm{i}}\right]$ ipini dotsat boy.ERG ø.ABs buy aux.A3sE3s-C apple.D.DAT put aux.A3sD3sE1s prezidxoa.

price.D.ABS

'I put the price on the apple that the boy bought'

f. [[Mutilek $e_{\mathrm{i}}$ erosi dauen] sagarragaz $]$ ein dot boy.ERG ø.ABs buy aux.A3sE3s-C apple.D.INSTR make aux.A3sE1s pastela.

cake.D.ABS

'I made the cake with the apple that the boy bought'

The results of the second cloze test shows that when the gap is an indirect object or an adjunct, the two groups allow relativization under Case matching, that is, when the Case of the head within the main clause matches the Case of the gap within the relative clause $(9 \mathrm{a}-\mathrm{d})$. For example, both mutileri 'boy' and the gap have dative Case (9a). 
(9) a. $\left[\left[e_{\mathrm{i}}\right.\right.$ Sagarra emon dotzaten $]$ mutileri $\left.{ }_{\mathrm{i}}\right]$ eskatu ø.DAT apple.D.ABs give aux.A3sD3se1s-c boy.D.DAT ask dotsat etortzeko aux.A3SD3se1s to come

'I have asked the boy that I gave the apple to to come'

b. [[Atzo $e_{\mathrm{i}}$ etorri nintzen] mutilegaz $\left.\mathrm{i}_{\mathrm{i}}\right]$ etorri da Idure geur. yesterday ø.soc come aux.A1s-C boy.D.Soc come aux.A3s Idure today 'Idure came today with the boy I came with yesterday'

c. [ $e_{\mathrm{i}}$ Urten naien $]$ etxetik $\left.\mathrm{i}_{\mathrm{i}}\right]$ dator Antxon. ø.ELA leave be.A1s-c house.D.INE come.A3s Antxon

'Antxon is coming from the house that I just left'

d. [ $\left[e_{\mathrm{i}}\right.$ Baloie erosi doten] mutilentzako $\left.{ }_{\mathrm{i}}\right]$ dire futboleko ø.BEN ball.D.ABs buy aux.A3se1s-C boy.D.BEN be.A3pl football. zapatak. GEN shoe.D.pl

'The cleats are for the boy that I bought the ball for'

Additionally, both groups rule out the RCs in which the RC head carries a different postposition to the one that the gap carries (i.e. there is no Case matching). These are some examples $(10 \mathrm{a}-\mathrm{d})$ :

(10) a. $\left[\left[e_{\mathrm{i}}\right.\right.$ Sagarra emon dotsaten $\quad{ }^{*}$ mutileri $_{\mathrm{i}} /{ }^{*}$ mutilegaz $_{\mathrm{i}}$ ø.DAT apple.D.ABS give aux.A3sD3sE1s-C boy.D.DAT/boy.D.SOC korritzen dot.

run aux.A3sE3s

'I run with the boy that I gave the apple to'

b. $\left[\left[e_{\mathrm{i}}\right.\right.$ Baloie ekarri dotsaten $] \quad{ }^{*}$ mutileri $_{\mathrm{i}} /{ }^{*}$ mutilegaitzik $\left.\mathrm{i}_{\mathrm{i}}\right]$ ø.DAT ball.D.ABs bring aux.A3sD3sE1s-C boy.D.DAT/boy.D.MOT etorri nai.

come aux.A1s

'I came because of the boy that I gave the apple to'

c. $\left[\left[e_{\mathrm{i}}\right.\right.$ Etorri nintzen] ${ }^{*}$ mutilegaz $_{\mathrm{i}} /{ }^{*}$ mutilentzako $\left.\mathrm{i}_{\mathrm{i}}\right] \mathrm{da}$ sagarra. ø.soc come aux.A1s-C boy.D.soc/ boy.D.Ben be.A1s apple.D.ABS 'The apple is for the boy that I came with'

d. $\left[e_{\mathrm{i}}\right.$ Joan nintzen] ${ }^{*}$ etxera $\mathrm{i}_{\mathrm{i}} /{ }^{*}$ etxiegaitzik $\left.\mathrm{i}_{\mathrm{i}}\right]$ galdetu deu ø.ALL go aux.A1s-C house.D.soc/house.D.MOT ask aux.A3E3s.

Bitorrek.

Bitor.ERG

'Bitor asked about the house I went to'

Variations between the two groups arise when the RC has an indirect object or adjunct gap and the RC head functions as the subject or object of the main clause. MB I allows RCs with indirect object and adjunct gap and the RC head as the subject or direct object of the main clause (11a-d), while MB II does not (12a-d). In addition, as shown in (11a-d), the head carries the postposition that is required by the 
relative clause rather than carrying the ergative or absolutive Case that would normally be required by the main clause. Also notice in (12a-d) that the main auxiliary verb agrees in number with the head of the RC.

(11) Mundaka Basque I

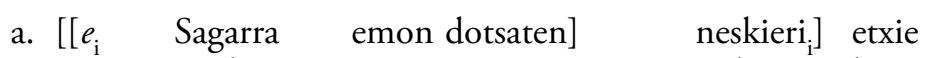

ø.DAT apple.D.ABS give aux.A3sD3sE1s-C girl.D.DAT house.D.ABS erosi deu.

buy aux.A3SE3s

'The girl that I gave the apple to bought the house'

b. [[Mutilek $e_{\mathrm{i}}$ erosi dauen] sagarrari $\left.\mathrm{i}_{\mathrm{i}}\right]$ erosi ein dot. boy.ERG $\emptyset . A B s$ buy aux.A3se3s-C apple.D.DAT buy do aux.A3sE1s 'I have bought the apple that the boy put the price on'

c. $\left[\left[e_{\mathrm{i}}\right.\right.$ Etorri nintzen $]$ neskiegaz $\left.\mathrm{i}\right]$ etxie erosi deu. ø.sOc come aux.A1s-C girl.D.sOC house.D.ABs buy aux.A3sE3s 'The girl that I came with bought the house'

d. [[Mikel $e_{\mathrm{i}}$ jolasten dabilen] baloigaz $\mathrm{i}_{\mathrm{i}}$ amak ekarri Mikel. ABs ø.soc playing aux.A1s-C ball. D SOC mom.ERG buy deu. auX.A3se3s

'Mom has brought the ball that Mikel is playing with'

(12) Mundaka Basque II

a. $\left[e_{\mathrm{i}}\right.$ Sagarra emon dotsaten $] \quad{ }^{*}$ neskieri $_{\mathrm{i}} /{ }^{*}$ neskiek $\left._{\mathrm{i}}\right]$ ø.DAT apple.D.ABS give aux.A3sD3sE1s-C girl.D.DAT / girl.D.ERG etxie erosi deu. house.D.ABs buy aux.A3sE3s

'The girl that I gave the apple to bought the house'

b. [[Mutilek $e_{\mathrm{i}}$ erosi dauen] ${ }^{*}$ sagarrari $\mathrm{i}_{\mathrm{i}} /{ }^{*}{ }^{*}$ sagarra $\left.{ }_{\mathrm{i}}\right]$ erosi ein boy.ERG $\emptyset . A B S$ buy aux.A3sE3s-C apple.D.DAT/apple.D.ABs buy do dot.

aux.A3se1s

'I have bought the apple that the boy put the price on'

c. $\left[\left[e_{i} \quad\right.\right.$ Etorri nintzen $]{ }^{*}$ neskiegaz $/{ }^{*}{ }^{*}$ neskiek $\left._{\mathrm{i}}\right]$ etxie erosi ø.sOC come aux.A1s-C girl.D.sOc/ girl.D.ERG house.D.ABs buy deu.

aux.A3se3s

'The girl that I came with bought the house'

d. [[Mikel $e_{\mathrm{i}}$ jolasten dabilen] * ${ }^{*}$ baloiegaz $_{\mathrm{i}} /{ }^{*}$ baloie $_{\mathrm{i}}$ ] amak Mikel. ABS ø.soc playing aux.A1s-C ball.D.sOC / ball.D.ABS mom.ERG ekarri deu.

bring aux.A3sE3s

'Mom has bought the ball that Mikel is playing with' 
When a phrase can be relativized in a clause, it is said to be accessible to relativeclause formation. Accessibility to relativization is understood according to the morphosyntactic features of the relativized phrase. It is generally admitted that relativization accessibility displays the following syntactic hierarchy (Keenan \& Comrie 1977):

(13) subject $>$ direct object $>$ indirect object $>$ adverbial (adjunct)

No superiority regarding accessibility appear in both Mundaka Basque varieties between subjects and objects. Nonetheless, while MB II shows accessibility only until the direct object, MB I shows a wider relativization spectrum: MB I allows relativization of indirect objects and adjuncts when the head of the RC is in subject or object position.

Languages in contact may lend one language to the reduced or incomplete feature development frequently described in terms of simplification (Andersen 1982, Dorian 1989, Ferguson 1977, 1982, Guitart 1982, Silva-Corvalán 1994, 1995). Mundaka Basque is in contact with Spanish. In this last language, relativization of an indirect object and any type of adjunct is always possible. This is illustrated in examples (14ad) and (15a-d).

(14) a. [La chica [a quien di $e$ la manzana]] compró la casa the girl.NOM to whom give.3s ø.DAT the apple.ABs buy.3s the house. 'The girl that I gave the apple to bought the house'

b. Conoces a [las chicas [con las que he venido e]]? know.2s the girls.ACC with the that have.3s come.part ø.soc 'Do you know the girls I came with?'

c. [La pizzeria [de donde estoy saliendo $e]$ hace pizzas the pizzeria.NOM from which be.1s leaving ø.INE make.3s pizzas buenas good

'The pizzeria that I'm leaving from makes good pizzas'

d. No ves [al chico [para quien he comprado el balón $e$ ]] no see.2s the boy.ACC for whom have.1s buy.part. the ball 'You don't see the boy that I bought the apple for'

(15) a. Paseo con [la chica [a quien di $e$ la manzana] $]$ walk.1s with the girl to whom give.3s ø.DAT the apple 'I walk with the girl that I gave the apple to'

b. Me preguntas por [las chicas [con las que he venido me ask.2s about the girls with the that have.3s come.part e]]?

ø.SOC

'Do you ask about the girls I came with?

c. Me preguntas por [la pizzeria [de donde estoy saliendo $e]$ ] me ask.2s about the pizzeria from which be.1s leaving ø.INE 'Do you ask me about the pizzeria that I'm leaving from?' 
d. Jon está hablando con el chico para quien he comprado el balón Jon be.3s speaking with the boy for whom have.1s buy.part. the ball 'Jon is speaking with that boy that I bought the ball for'

In (14a-d) the gap is in dative or adjunct position and the head of the RC is in subject or object position. In (15a-d) the gap is also in dative or adjunct position but the head of the RC is in adjunct position. As mentioned above, as opposed to MB II, in MB I the syntactic configuration of (14a-d) is grammatical. However, direct influence of Spanish cannot justify this grammaticality because if it did, MB I would also allow RCs with the gap in dative or adjunct position and the head of the RC in adjunct position (15a-d), but it does not.

On the contrary, the variety that shows simplification is MB II as it has a narrower relativization spectrum than MB I. Furthermore, given the fact that group $\mathrm{B}$ was in Model D in school and, therefore, had Standard Basque as the language of instruction, MB II shows simplification due to its contact with Standard Basque. Evidence for this comes from relativization accessibility of Standard Basque, which shows the same relativization accessibility as MB II: the indirect object shows restrictions and adjuncts resist relativization regardless the position of the RC head (Oyharçabal 2003). Thus, it appears reasonable to conclude that Standard Basque caused simplification of the accessibility hierarchy in MB II RCs as MB II, as opposed to MB I, has relativization accessibility only until direct object, too.

\section{Conclusion}

In this article two varieties within Mundaka Basque have been identified among two different generations from Mundaka. The difference between these two Mundaka Basque varieties was detected through the RC construction: MB I allows RCs with indirect object and adjunct gap and the RC head as the subject or direct object of the main clause, while MB II does not. A summary of possible relativization in MB I and in MB II is shown in Table 1 and Table 2 respectively. Superiority regarding accessibility appears in both varieties in indirect objects and adjuncts but in different levels. Concretely, MB II has a narrower relativization spectrum than MB I, which is the result of simplification of relativization accessibility in MB II caused by Standard Basque.

Table 1

Grammaticality of Relativization in Mundaka Basque I

\begin{tabular}{|c|c|c|c|c|}
\hline $\begin{array}{ll} & F G R C \\
F G \text { gap } & \end{array}$ & Subject & Direct Object & Adjunct & Matching \\
\hline Subject & $\sqrt{ }$ & $\checkmark$ & $\checkmark$ & \\
\hline Direct Object & $\checkmark$ & $\checkmark$ & $\checkmark$ & \\
\hline Indirect Object & $\checkmark$ & $\checkmark$ & $x$ & $\checkmark$ \\
\hline Adjunct & $\checkmark$ & $\checkmark$ & $x$ & $\checkmark$ \\
\hline
\end{tabular}


Table 2

Grammaticality of Relativization in Mundaka Basque II

\begin{tabular}{|l|c|c|c|c|}
\hline FG gap & SG RC & Direct Object & Adjunct & Matching \\
\hline Subject & $\checkmark$ & $\checkmark$ & $\checkmark$ & \\
\hline Direct Object & $\checkmark$ & $\checkmark$ & $\checkmark$ & \\
\hline Indirect Object & $x$ & $x$ & $x$ & $\checkmark$ \\
\hline Adjunct & $x$ & $x$ & $x$ & $\checkmark$ \\
\hline
\end{tabular}

\section{References}

Amorrortu, E., 2000, Linguistic attitudes in the Basque Country: The social acceptance of a new variety. Doctoral dissertation, University of Southern California.

Andersen, R. W., 1982, Gramática de la lengua castellana. Madrid: Edaf.

Artiagoitia, X., 1992, "Why Basque Doesn't Relativise Everything». Syntax Theory and Basque Syntax, ed. by Lakarra \& Ortiz de Urbina, 11-35. Diputación Foral de Gipuzkoa, San Sebastián.

Azurmendi, M. J., N. Larrañaga and J. Apalategi, 2008, «Bilingualism, identity and citizenship in the Basque Country». Bilingualism and Identity, ed. by Niño-Murcia, Mercedes and Jason Rothman. Amsterdam: John Benjamins Publishing Company.

Azurmendi, M. J. and Martinez de Luna, I., 2006, The Case of Basque: Past, Present and Future. Andoain: Soziolinguistika Klusterra.

Bonaparte, L. L., 1863, Carte des sept provinces basques montrant la delimitation actuelle de l'Euskara et sa division en dialectes et varietés. London

Cenoz, J., 2006, Mapping regional minority languages in Europe: Basque in Spain. http:// www.ebos.com.cy/susdiv/uploadfiles/D17_ResearchPaper_1.pdf. Spain: UPV/EHU.

Dorian, N., 1989, Investigation obsolescence. Cambridge: Cambridge University Press.

Etxeberria, F. and Elosegi, K., 2008, «Basque, Spanish and Immigrant Minority Languages in Basque Schools». Teaching through Basque: achievements and challenges, ed. by Jasone Cenoz, 69-84. Great Britain: Cromwell Press Ltd.

EUSTAT (Basque Statistics Office). 2004.

Ferguson, C. A., 1977, "Absence of copula and the notion of simplicity: A study of normal speech, baby talk, foreigner talk and pidgin». In Dell Hymes ed., Pidginization and creolization of language. Cambridge: Cambridge University Press. 141-150.

—, 1982, Simplified register and linguistic theory. In L. Obler \& L. Menn ed., Exceptional language and linguistics. New York: Academic. 49-66.

Gardner, N., 2000, Basque in Education in the Basque Autonomous Community. VitoriaGasteiz: Eusko Jaurlaritza/Gobierno Vasco.

Gardner, N. and M. Zalbide, 2005, «Basque acquisition planning». In Azurmendi \& Martinez de Luna (eds.), 55-72. Berlin: Mouton de Guyter.

Grin, F. and F. Vaillancourt, 1999, The Cost-effectiveness Evaluation of Minority Language Policies: Case Studies on Wales, Ireland and the Basque Country. Flensburg: European Centre for Minority Issues (ECMI). 
Guitart, J. M., 1982, «On the use of the Subjuntive among Spanish-English bilinguals». Words 33:59-67.

Haddican, B., 2005, «Standardization, Functional Shift and Language Change in Basque», Estudios de Sociolinguistica, 5(2).

Hadley, G. S. and Naaykens, J. E., 1997, "An investigation of the selective deletion cloze test as a valid measure of grammar-based proficiency in second language learning». Niigata Studies in Foreign Languages and Cultures 3, 111-118.

Irizar, P., 1992, Morfología del verbo auxiliar alto navarro septentrional (vol. 2). Navarran Government and Basque Language Academy.

Keenan, E. and B. Comrie, 1977, "Noun Phrase Accessibility and Universal Grammar», Linguistic Inquiry 8, 63-99.

Luque, M.-L., 2004, Adquisición - aprendizaje del Euskara a través de la Inmersión Total Precoz (2-4 años): Análisis psico-socio-lingüistico-pedagógico. Bilbao, Bizkaia: UPV/EHU dissertation.

Martinez de Luna, I. and K. Berrio-Otxoa, 2000, Etorkizuna aurreikusten 99: Euskal herriko gaztetxoak eta Euskara. Donostia-San Sebastián: I. Martínez de Luna.

Michelena, L., 1954/2011, "La posición fonética del dialecto vasco del Roncal». In J. A. Lakarra \& I. Ruiz Arzalluz (eds.), Luis Michelena. Obras completas (vol. 7, pp. 661647). Donostia-San Sebastián, Vitoria-Gasteiz: Diputación Foral de Guipúzcoa, University of the Basque Country. (Reprinted from Via Domitia, 1, pp. 123-157)

—, 1977/2011, Fonética histórica vasca (Publicaciones del Seminario "Julio de Urquijo»). In J. A. Lakarra \& I. Ruiz Arzalluz (eds.), Luis Michelena. Obras completas (vol. 6). Donostia-San Sebastián, Vitoria-Gasteiz: Diputación Foral de Guipúzcoa, University of the Basque Country. (Reprinted from Fonética histórica vasca [Publicaciones del Seminario "Julio de Urquijo»], 2nd. ed., Donostia-San Sebastián: Diputación Foral de Guipúzcoa).

Olano, M., 2000, "Gipuzkoa ondoko bi hizkera nafar: Areso et Leitzako paradoxa». In Koldo Zuazo, ed., Dialektologia Gaiak. Gasteiz: Arabako Foru Aldundia. 123-147.

Oyharçabal, B., 2003, «Relative clauses». A Grammar of Basque, ed. by J. I. Hualde and J. Ortiz de Urbina, 762-823. Mouton de Gruyter: Berlin.

Sierra, J., 2009, "Assessment of Bilingual Education in the Basque Country». Teaching through Basque: achievements and challenges, ed. by J. Cenoz, 39-47. Great Britain: Cromwell Press Ltd.

Silva-Corvalán, C., 1994, Language Contact and Language Change: Spanish in Los Angeles. Oxford: Clarendon Press.

—, 1995, «The gradual loss of mood distinctions in Los Angeles». Language Variation and Change, 6.

Tovar, A., 1959, El euskera y sus parientes. Madrid: Minotauro.

Trask, R. L., 1997, The history of Basque. London: Routledge.

Vicente, L., 2002, Prenominal Relatives in Basque and Antisymmetry. Bilbao, Bizkaia: University of Deusto BA dissertation.

Zalbide, M. and J. Cenoz, 2009, «Bilingual Education in the Basque Autonomous Community: Achievements and Challenges». Teaching through Basque: achievements and challenges, ed. by J. Cenoz, 5-20. Great Britain: Cromwell Press Ltd.

Zuazo, K., 1997, «Oiartzungo hizkeraren kokagunea». Fontes Linguae Vasconum, 76, 397-425.

—, 1998a, «Euskalkiak, gaur». Fontes Linguae Vasconum, 78, 191-233. 
—, 1998b, «Nafarroako euskal hizkerak». In Iñaki Camino (ed.), Nafarroako hizkenak. Bilbo: Udako Euskal Unibertsitatea, 1-21.

-, 2010, El euskera y sus dialectos. Alberdania.

Zubiri, J. J., 2000, «Arano eta Goizuetako hizkera». In K. Zuazo (ed.), Dialektologia Gaiak. Gasteiz: Arabako Foru Aldundia. 85-120.

Ager Gondra

SUNY-Purchase

735 Anderson Hill Road, Purchase, NY 10577, USA

(914) 251-6000

ager.gondra@purchase.edu 